\title{
PROTEIN KINASE C IS NOT INVOLVED IN SECRETION BY PERMEABILIZED HUMAN NEUTROPHILS
}

\author{
James E. Smolen, ${ }^{*} †$ Sally Jo Stoemr and Dana Bartone \\ Department of Pediatrics, Section of Hematology/Oncology, and *Department of Pathology, University of \\ Michigan, Ann Arbor, MI 48109, U.S.A.
}

(Received 18 November 1988; and accepted 23 March 1989)

\begin{abstract}
The generally accepted sequence of intracellular signal transduction involves: (1) cell surface receptor-ligand interactions; (2) activation of G-proteins; (3) activation of phospholipase C, leading to inositol phosphate $\left(\mathrm{IP}_{3}\right)$ and diacylglycerol production; (4) parallel mobilization of intracellular $\mathrm{Ca}^{2+}$ by $\mathrm{IP}_{3}$, and; (5) activation of protein kinase $\mathrm{C}$ (PKC) by diacylglycerol and $\mathrm{Ca}^{2+}$, leading to; (6) cellular responses. Human neutrophils appear to utilize this cascade, at least in general, and some, but not all, elements of the intracellular signal cascade known to be operating in intact cells also function in permeabilized cell systems. We have previously shown that permeabilized neutrophils can be induced to secrete lysosomal enzymes in response to elevated levels of $\mathrm{Ca}^{2+}$ alone and this secretion can be synergistically enhanced by the presence of guanine nucleotides. We now show that $\mathrm{Ca}^{2+}$, in the presence and absence of guanine nucleotides, can stimulate the production of soluble inositol phosphates. Furthermore, neomycin, a putative inhibitor of phospholipase C, can block $\mathrm{Ca}^{2+}$-induced secretion. These data thus suggest a role for phospholipase $\mathrm{C}$ activity or its products in the transduction process. The next enzymatic activity 'downstream' is PKC. Consequently, we looked at the role $\mathrm{Mg}-\mathrm{ATP}$, one of the substrates of PKC, plays in degranulation by permeabilized neutrophils. We found no obligatory role for this nucleotide in the secretory process. We then looked at the activity of oleoyl-acetylglycerol (OAG), a synthetic diacylglycerol and PKC agonist, on degranulation. We found that OAG was largely additive with $\mathrm{Ca}^{2+}$. Another PKC agonist, phorbol myristate acetate (PMA), also did not display notable synergy. Finally, inhibitors of PKC activity were not capable of blocking secretion, either in the presence or absence of guanine nucleotides. Thus, while circumstantial evidence seems to point towards a requirement for phospholipase $\mathrm{C}$ activation and diacylglycerol production in secretion, we were unable to demonstate the next putative step in signal transduction, namely activation of PKC.
\end{abstract}

Key words." Neutrophil, permeabilization, phospholipase C, protein kinase $\mathrm{C}$, intracellular $\mathrm{Ca}^{2+}$, degranulation, guanine nucleotides.

\section{INTRODUCTION}

NeUTROPHILS and other secretory cells appear to share some common pathways of signal transduction, in which cell surface interactions lead ultimately to cellular responses. In general, it appears that a wide variety of membrane receptors are coupled to guanine nucleotide binding proteins (G-proteins) [1-4], which are similar [5-7], but not necessarily identical [7$12]$, to the $G_{i}$ proteins found in the adenylate cyclase system [13]. The activated G-proteins can stimulate a polyphosphoinositide-depen-

†To whom correspondence should be addressed: Dr J. E. Smolen, M7510 MSRB I. Box 0684, Division of Pediatric Hematology/Oncology, University of Michigan, Ann Arbor, MI 48109-0684, U.S.A dent phospholipase C [14], leading to the generation of inositol 1,4,5-trisphosphate $\left(\mathrm{IP}_{3}\right)$ and diacylglycerols [15-19]. IP ${ }_{3}$ has been shown to liberate $\mathrm{Ca}^{2+}$ from intracellular sources [2022], while diacylglycerol has been shown to be an activator of protein kinase $C$ [23]; both processes are felt to lead ultimately to neutrophil responses such as lysosomal enzyme release and superoxide anion generation.

Permeabilized cells have contributed substantially to an understanding of stimulus -response coupling in neutrophils. It has been reported that $\mathrm{IP}_{3}$ induces the release of intracellular $\mathrm{Ca}^{2+}$ from putative stores in the endoplasmic reticulum of permeabilized neutrophils [20]. We and others have shown that elevated levels of $\mathrm{Ca}^{2+}$ alone, which might be partially attributed to 
increases in $\mathrm{IP}_{3}$ in intact cells, is a sufficient stimulus for secretion from permeabilized cells [24-29]. This $\mathrm{Ca}^{2+}$-induced degranulation from permeabilized neutrophils is as rapid and extensive as that found with intact cells [30]. We and others have also shown that guanine nucleotides interact synergistically with $\mathrm{Ca}^{2+}$ to induce lysosomal enzyme release [27,31], implicating G-proteins in the functioning of this model system. Finally, we have shown that, at the proximal end of the transduction pathway, cell surface receptors for the chemotactic peptide f-Met-Leu-Phe are coupled to G-proteins in the permeabilized neutrophil and that the affinities of these receptors can be rapidly altered by exposure to guanine nucleotides [2].

It has been reported that neomycin, an inhibitor of phospholipase $\mathrm{C}$, can block receptor-mediated responses of intact secretory cells $[32,33]$. This suggests that the formation of $\mathrm{IP}_{3}$ and/or diacylglycerol are necessary components of stimulus-response coupling. We have also reported that neomycin can block $\mathrm{Ca}^{2+}$-induced secretion from permeabilized neutrophils [30], albeit at relatively high concentrations. These data, along with stimulated production of soluble inositol phosphates following exposure to $\mathrm{Ca}^{2+}$, suggested that phospholipase $\mathrm{C}$ activation was important for secretion. We therefore sought evidence for the involvement of the next putative step in the transduction pathway, namely activation of PKC by diacylglycerol. While our data suggest a crucial role for phospholipase $C$, we have not been able to demonstrate conclusively a role for protein kinase $\mathrm{C}$ in lysosomal enzyme release by permeabilized cells.

\section{MATERIALS AND METHODS}

\section{Reagents}

PMA, OAG, Gpp(NH)p (5'-guanylyl imidodiphosphate), GTP (guanosine $5^{\prime}$-triphosphate), and digitonin were purchased from Sigma Chemical Company, St. Louis, MO. GTP- $\gamma$-S (guanosine 5'-O(3-thiotriphosphate)) was obtained from Bochringer Mannheim, Indianapolis, IN. Stock solutions of OAG were prepared in chloroform. IP $_{3}$ determination kits were purchased from Amersham.

\section{Preparation of cell suspensions}

Heparinized $(10 \mathrm{U} / \mathrm{ml})$ venous blood was obtained from healthy adult donors. Purified preparations of neutrophils were isolated from this blood by means of Hypaque/Ficoll gradients [34] followed by standard techniques of dextran sedimentation and hypotonic lysis of erythrocytes [35]. This allowed studies of cell suspensions containing $98 \pm 2 \%$ neutrophils with few contaminating platelets or erythrocytes. The cells were washed and finally suspended in a buffer consisting of $138 \mathrm{mM} \mathrm{NaCl}, 2.7 \mathrm{mM} \mathrm{KCl}, 8.1 \mathrm{mM}$ $\mathrm{Na}_{2} \mathrm{HPO}_{4}, \quad 1.5 \mathrm{mM} \quad \mathrm{KH}_{2} \mathrm{PO}_{4}, 1 \mathrm{mM} \quad \mathrm{CaCl}_{2}$, and $0.6 \mathrm{mM} \mathrm{MgCl}, \mathrm{pH} 7.4$ (Buffer $\mathrm{P}$ ). For permeabilization studies, the cells were instead washed once and resuspended in Buffer $\mathrm{K}(100 \mathrm{mM} \mathrm{KCl}, 20 \mathrm{mM}$ $\mathrm{NaCl}, 1 \mathrm{mM}$ EGTA, and $30 \mathrm{mM}$ HEPES, pH 7.0).

\section{Neutrophil permeabilization}

Permeabilization was performed as previously described [25]. In essence, stock solutions of digito$\operatorname{nin}(1 \mathrm{mg} / \mathrm{ml}$ in Buffer $\mathrm{K})$ were prepared daily. Neutrophils $\left(25 \times 10^{6} / \mathrm{ml}\right)$ suspended in Buffer $\mathrm{K}$ were preincubated for $10 \mathrm{~min}$ at $37^{\circ} \mathrm{C}$. Incubation was at $37^{\circ} \mathrm{C}$ for $25 \mathrm{~min}$ with $10 \mu \mathrm{g} / \mathrm{ml}$ digitonin; the cell suspension was mixed every $5 \mathrm{~min}$.

\section{Lysosomal enzyme release}

Following permeabilization, neutrophils were used without washing. They were suspended in Buffer $\mathrm{K}$ at a concentration of $5 \times 10^{6} / \mathrm{ml}$ with the desired concentration of free $\mathrm{Ca}^{2+}$, which was determined for the buffer using a $\mathrm{Ca}^{2+}$ electrode [36]. The cells were then incubated at $37^{\circ} \mathrm{C}$ for $5 \mathrm{~min}$; cells incubated without calcium and intact neutrophils were employed as routine controls. The cell suspensions were then centrifuged at $750 \times g$ for $10 \mathrm{~min}$. Aliquots of the supernatants were taken for standard determinations of $\beta$-glucuronidase [37] (an enzyme found exclusively in azurophil granules), lysozyme [38] (an enzyme found in both specific and azurophil granules), vitamin $\mathbf{B}_{12}$ binding protein [39] (a component of specific granules alone), and LDH activities [40] (a cytosolic enzyme).

In some cases, the responses of intact cells were measured. For experiments examining stimulation by PMA and OAG, the neutrophils were exposed to the indicated concentrations of the agents in Buffer $K$, followed by assays of supernatant content. When OAG was used as a reagent, aliquots of a stock solution prepared in chloroform were placed directly into the individual experimental tubes and the chloroform was evaporated with $N_{2}$. The remaining reagents were added and each tube was sonicated for $20 \mathrm{~s}$ in order to disperse the lipid in the aqueous solution. 


\section{Phospholipase C activity}

Phospholipase $\mathrm{C}$ activity was measured by determinations of $\mathrm{IP}_{3}$ generation [41]. Permeabilized neutrophils suspended in Buffer $\mathrm{K}$ were incubated at $37^{\circ} \mathrm{C}$ for $30 \mathrm{~s}$ with $7 \mu \mathrm{M} \mathrm{Ca}^{2+}$ plus $5 \mu \mathrm{M} \mathrm{GTP}-\gamma-\mathrm{S}$ or $100 \mu \mathrm{M} \mathrm{Ca}^{2+}$ without GTP-y-S. The reaction was stopped by precipitation of proteins with perchloric acid. $I P_{3}$ was extracted and assayed according to the instructions of a radiochemical assay kit (Amersham).

\section{RESULTS}

\section{Evidence for involvement of phospholipase $C$}

We previously reported that $\mathrm{Ca}^{2+}$-induced lysosomal enzyme release from permeabilized neutrophils could be inhibited by neomycin [30], an antagonist of phospholipase C. We also reported that guanine nucleotides synergistically lower the $\mathrm{Ca}^{2+}$ concentrations required for secretion by permeabilized neutrophils [31]. We now show that secretion in the guanine nucleotide-enhanced system also appears to be sensitive to neomycin. Figure 1 shows the effects of $500 \mu \mathrm{M}$ neomycin on $\mathrm{Ca}^{2+}$-induced release of vitamin $B_{12}$ binding protein (a constituent of specific granules) in the presence or absence of GTP- $\gamma-\mathrm{S}$. $\mathrm{Ca}^{2+}$-dependent secretion was not affected by the presence of neomycin at this concentration. When $5 \mu \mathrm{M}$ GTP- $\gamma-\mathrm{S}$ was present along with $\mathrm{Ca}^{2+}$, vitamin $\mathrm{B}_{12}$ binding protein release was enhanced; this effect was synergistic at low concentrations of the cation. However, when neomycin was added, enhancement by GTP- $\gamma$-S was blocked and enzyme release was similar to (or even less than) that found with $\mathrm{Ca}^{2+}$ alone. When secretion of $\beta$ glucuronidase (a constituent of azurophil granules alone) and lysozyme (a constituent of both specific and azurophil granules) was monitored, similar results were found (not shown).

Inhibition by neomycin thus suggested that phospholipase $\mathrm{C}$ activity might be involved in $\mathrm{Ca}^{2+}$-induced secretion, both in the presence (Fig. 1) and absence of guanine nucleotides [30]. That the conditions used in these experiments to stimulate secretion can result in inositol phosphate production has been demonstrated by other researchers [42]. We confirmed this in preliminary experiments which showed that $\mathrm{IP}_{3}$ production by permeabilized neutrophils increased from $0.53 \pm 0.19 \mathrm{nmol} / 10^{6}$ cells to $1.02 \pm 0.48 \mathrm{nmol} / 10^{6}$ cells $(n=3 ; \pm$ S.E.M.) following a $30 \mathrm{~s}$ exposure to $7.6 \mu \mathrm{M} \mathrm{Ca}^{2+}$ plus $5 \mu \mathrm{M}$ GTP- $\gamma-\mathrm{S}$. Ca ${ }^{2+}(100 \mu \mathrm{M})$ alone resulted in the generation of $3.26 \pm 1.24 \mathrm{nmol} / 10^{6}$ cells.

\section{Lack of $\mathrm{Mg}-A T P$ requirement}

Since phospholipase $\mathrm{C}$ activity was clearly elevated in permeabilized cells undergoing secretion, it seemed possible that the formation of diacylglycerol along with residual ATP present in these cell suspensions might activate PKC. This was clearly a possibility since preliminary experiments by $\mathrm{Dr} \mathrm{K}$. Balazovich (personal communication) showed that permeabilized neutrophils retained $65 \%$ of the total cellular PKC activity as measured by histone phosphorylation. It was suspected that if activation of

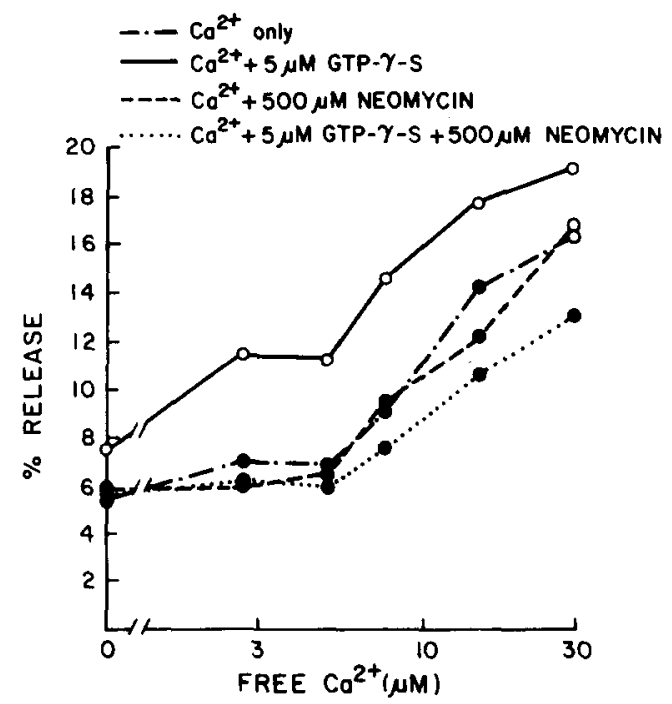

FIG. 1. Inhibition of $\mathrm{Ca}^{2+}$-induced release of vitamin $\mathbf{B}_{12}$ binding protein by neomycin. Permeabilized neutrophils were stimulated with various concentrations of $\mathrm{Ca}^{2+}$ in the presence or absence of GTP- $\gamma-\mathrm{S}$ $(5 \mu \mathrm{M})$ and/or neomycin $(500 \mu \mathrm{M})$, as indicated. Release of vitamin $\mathbf{B}_{12}$ binding protein is shown above and solid symbols indicate points which were significantly $(P<0.05, n=2-4)$ different from those containing GTP- $\gamma-\mathrm{S}$ and $\mathrm{Ca}^{2+}$ alone. 

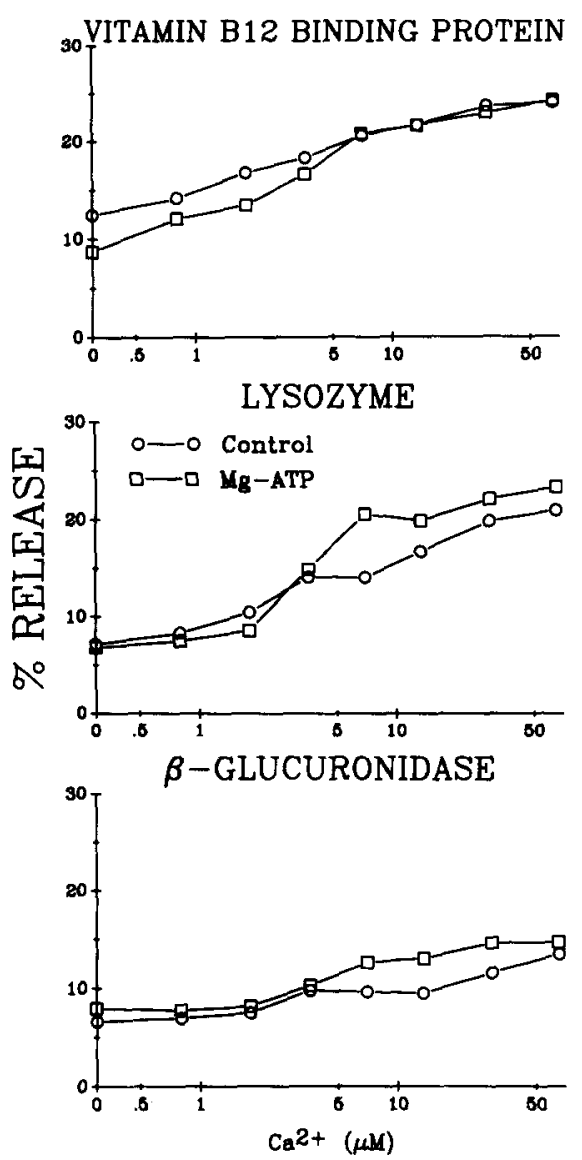

FIG. 2. Effect of $\mathrm{Mg}$-ATP on $\mathrm{Ca}^{2+}$-induced secretion in the presence of guanine nucleotides. Permeabilized human neutrophils were stimulated in the presence of $100 \mu \mathrm{M} \mathrm{Gpp}(\mathrm{NH}) \mathrm{p}$ and various concentrations of $\mathrm{Ca}^{2+}$, with ( $\square$ ) and without (O) Mg-ATP (1 mM). Release of vitamin $B_{12}$ binding protein (top), lysozyme (middle), and $\beta$-glucuronidase (bottom) are shown from a typical experiment, of which at least two were performed.

this enzyme were involved in secretion, the addition of Mg-ATP (an obligate substrate for PKC) should enhance observed release. Figure 2 shows that while the presence of $1 \mathrm{mM}$ Mg-ATP had little or no effect on $\mathrm{Ca}^{2+}$-induced secretion of vitamin $B_{12}$ binding protein in the presence of guanine nucleotides, the release of lysozyme and $\beta$-glucuronidase was slightly enhanced by $\mathrm{Mg}$-ATP.

In order to examine this situation more criti- cally, a larger number of experiments was conducted to look for the effects of Mg-ATP on secretion in both the presence and absence of guanine nucleotides. As shown in Table 1, we first examined $\mathrm{Ca}^{2+}$-induced secretion, both in the presence and absence of GTP- $\gamma-S$, using our standard procedures and looked for modulation by $1 \mathrm{mM} \mathrm{Mg-ATP}$. The first conclusion to be drawn from these data was that exogenous $\mathrm{Mg}$-ATP was not required for secretion, because release proceeded well in the absence of this nucleotide. The second conclusion was that the addition of Mg-ATP potentiated degranulation only slightly. Significantly enhanced release of vitamin $\mathrm{B}_{12}$ binding protein and $\beta$-glucuronidase was found in the presence of Mg-ATP using vanishingly low (' 0 '; $<10^{-8} \mathrm{M}$ ) levels of $\mathrm{Ca}^{2+}$ alone. When low $(5 \mu \mathrm{M})$ levels of $\mathrm{Ca}^{2+}$ were employed, secretion of all these granule constituents was enhanced significantly. At high concentrations $(30 \mu \mathrm{M})$ of $\mathrm{Ca}^{2+}, \mathrm{Mg}$-ATP seemed to be inhibitory, but this was not statistically significant.

One of the problems with these studies was that the experiments performed in the 'absence' of Mg-ATP would actually have as much as 20$50 \mu \mathrm{M} \mathrm{Mg}$-ATP available from endogenous sources. Direct analysis of nucleotide contents by $\mathrm{Dr}$ K. Balazovich using HPLC indicated that actual ATP and GTP concentrations were below $5 \mu \mathrm{M}$, with some dinucleotide breakdown products (personal communication). In order to avoid any uncertainties with respect to residual nucleotide di- and tri-phosphates, permeabilized cells were washed free of this endogenous component. The results obtained with washed cells are shown in Table 2 and are qualitatively similar to those present in Table 1. Statistically significant increases in secretion were again observed at low levels of $\mathrm{Ca}^{2+}$. At higher $\mathrm{Ca}^{2+}$ concentrations, Mg-ATP was again inhibitory; this was statistically significant in the case of lysozyme. Thus, the effect of Mg-ATP depended upon the concentration of $\mathrm{Ca}^{2+}$ employed and the data in these two tables do not support the notion that PKC activity has an obligatory, stimulatory role in secretion by permeabilized neutrophils. 
TABLE 1. EFFECT OF Mg-ATP ON $\mathrm{Ca}^{2+}$-INDUCED SECRETION FROM PERMEABILIZED hUMAN NEUTROPHILS

\begin{tabular}{lcccc}
\hline & \multicolumn{5}{c}{ Unwashed cells } & \\
\hline & $\mathrm{Ca}^{2+}$ & GTP- $\gamma$-S & - Mg-ATP & + Mg-ATP \\
\cline { 2 - 5 } Vitamin B $_{12}$ & 0 & - & $9.5 \pm 3.0(n=11)$ & $11.5 \pm 3.3^{*}$ \\
Binding & 5 & - & $11.7 \pm 2.4(n=12)$ & $16.6 \pm 3.9^{*}$ \\
Protein & 30 & - & $27.8 \pm 4.6(n=6)$ & $21.8 \pm 4.0$ \\
& 0 & 5 & $18.9 \pm 9.9(n=3)$ & $34.4 \pm 15.6$ \\
& 5 & 5 & $19.3 \pm 5.0(n=4)$ & $17.8 \pm 5.3$ \\
\hline Lysozyme & 0 & - & $4.8 \pm 1.2(n=11)$ & $5.2 \pm 1.0$ \\
& 5 & - & $6.2 \pm 1.2(n=12)$ & $7.5 \pm 1.5^{*}$ \\
& 30 & 5 & $15.7 \pm 3.3(n=6)$ & $13.0 \pm 2.9$ \\
& 0 & $5.6 \pm 1.1(n=3)$ & $4.2 \pm 1.0$ \\
$\beta$-Glucuronidase & 5 & - & $10.8 \pm 1.7(n=11)$ & $10.9 \pm 2.0$ \\
& 0 & - & $11.3 \pm 1.6(n=12)$ & $12.8 \pm 1.9 \pm$ \\
& 5 & - & $15.2 \pm 2.5(n=6)$ & $13.7 \pm 2.4$ \\
& 30 & 5 & $16.4 \pm 3.0(n=3)$ & $17.7 \pm 2.7^{*}$ \\
& 0 & 5 & $16.1 \pm 2.5(n=4)$ & $18.1 \pm 3.0$ \\
\hline
\end{tabular}

Permeabilized neutrophils (unwashed) were stimulated with the indicated micromolar concentrations of $\mathrm{Ca}^{2+}$ and GTP- $\gamma-\mathrm{S}$ and in the presence $(+)$ and absence $(-)$ of $\mathrm{Mg}-\mathrm{ATP}(30-300 \mu \mathrm{M})$. Release of these granular constituents was measured as detailed in Materials and Methods. Results are given as the total percentage of celluar complement released following a $5 \mathrm{~min}$ incubation at $37^{\circ} \mathrm{C}( \pm$ S.E.M.); the number of experiments is given in parenthesis. Significance of differences between the presence and absence of $\mathrm{Mg}$-ATP was determined by a paired Student $t$-test. Levels of significance are: ${ }^{*} P<0.05$; $\dagger P<0.01 ; \ddagger P<0.002 ; \S P<0.0005$.

\section{Lack of synergy with PKC agonists}

We also used two agonists of PKC, namely 1-oleoyl-2-acetyl-sn-glycerol (OAG) and phorbol myristate acetate (PMA), to test directly for a role of this enzyme in $\mathrm{Ca}^{2+}$-induced secretion. As shown in Fig. 3, OAG, a diacylglycerol, was stimulatory by itself (see ' 0 ' $\mathrm{Ca}^{2+}$ ). The effects of OAG were largely additive to those of $\mathrm{Ca}^{2+}$. Some weak synergy was observed when the data were carefully analysed, but this was not obvious from the data and was probably not mechanistically significant.

The effect of PMA on $\mathrm{Ca}^{2+}$-induced secretion is shown in Fig. 4. PMA, like OAG, produced some additive enhancement of secretion, apparent even in the absence of $\mathrm{Ca}^{2+}$, but no synergy. In addition, enhancement of $\mathrm{Ca}^{2+}$-induced lysosomal enzyme release by both OAG and PMA was also found in the presence of guanine nucleotides and Mg-ATP ( $1 \mathrm{mM}$; not shown).

Because the additive effects of OAG and PMA could conceivably have been due to resi- dual whole cells in the permeabilized neutrophil preparation [25], it was necessary to look at the effects of these agonists on both intact and permeabilized cells. PMA and OAG induced substantial secretion of lysozyme and vitamin $\mathrm{B}_{12}$ binding protein from intact neutrophils; far smaller amounts of these granule constituents were released from permeabilized cells (data not shown). We made the conservative assumption that the cytosolic lactate dehydrogenase (LDH) which was not released from the neutrophils during permeabilization (approx. $21 \%$ ) was a measure of contaminating intact cells. These calculations suggested that 'intact cell' contamination could account for almost all of the additional secretion found in the presence of both OAG and PMA.

\section{Lack of inhibition by PKC antagonists}

The above data thus do not support the possibility that PMA and OAG can directly 
VITAMIN B12 BINDING PROTEIN
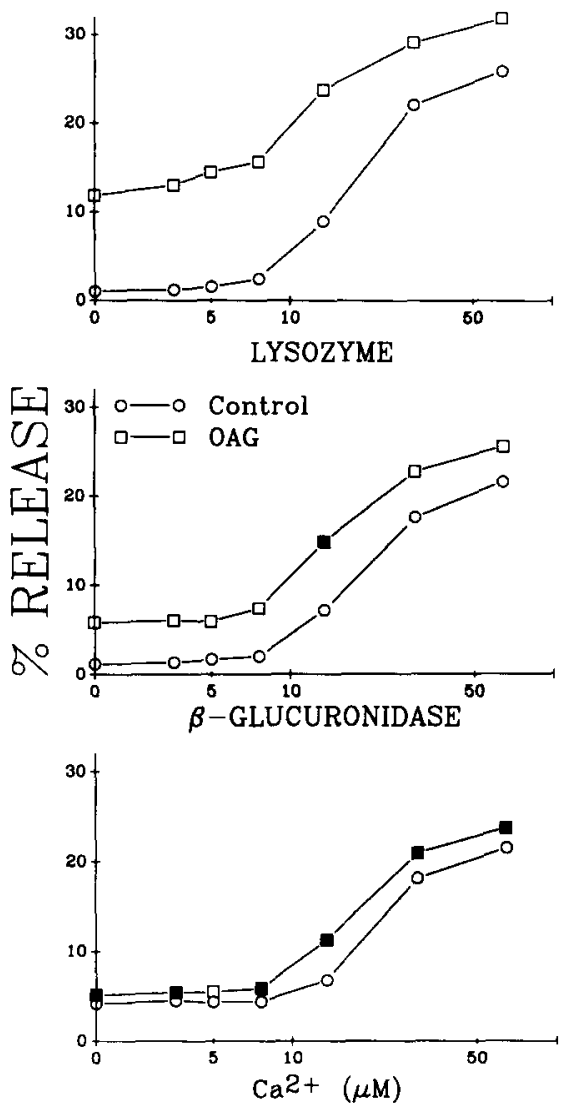

FIG. 3. Effect of $\mathrm{OAG}$ on $\mathrm{Ca}^{2+}$-induced secretion. Permeabilized neutrophils were washed (to remove cytosolic materials) and then stimulated with various concentrations of $\mathrm{Ca}^{2+}$ in the presence or absence of oleoyl-acetyl-glycerol $(\mathrm{OAG} ; 2 \mu \mathrm{g} / \mathrm{ml})$, as indicated. Release of lysozyme (Panel A), vitamin $\mathbf{B}_{\mathrm{t} 2}$ binding protein (Panel B), and $\beta$-glucuronidase (Panel C) are shown. Solid symbols denote those points which were significantly $(P<0.05, n=3)$ different from the control (without OAG).

activate procein kinase $\mathrm{C}$ in permeabilized neutrophils, resulting in secretion. To confirm this, we performed a number of additional tests of the role of PKC in this system. One such test was to see if either PMA or OAG could reverse neomycin-induced inhibition of synergy with guanine nucleotides. In the presence or absence of Mg-ATP, neither of these protein kinase C agonists restored synergy with GTP- $\gamma-S$ (data not shown). Another approach was to see if
VITAMIN B12 BINDING PROTEIN
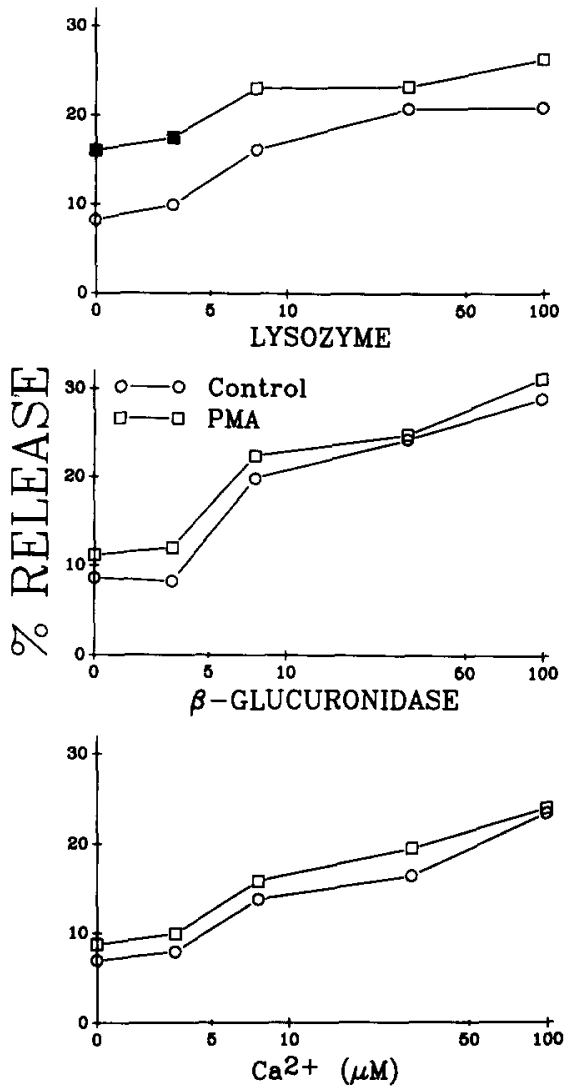

FIG. 4. Effect of PMA on $\mathrm{Ca}^{2+}$-induced secretion. Permeabilized neutrophils stimulated with various concentrations of $\mathrm{Ca}^{2+}$ in the presence or absence of phorbol myristate acetate (PMA; 3-10 ng/ml), as indicated. Release of lysozyme (Panel A), vitamin $B_{12}$ binding protein (Panel B), and $\beta$-glucuronidase (Panel C) are shown. Solid symbols denote those points which were significantly $(P<0.05, n=3)$ different from control.

inhibitors of protein kinase $\mathrm{C}$ had any substantial effect on secretion. As shown in Fig. 5, concentrations of $\mathrm{H}-7$ (a protein kinase $\mathrm{C}$ antagonist) which were inhibitory to intact cell function $[43,44]$ were without significant effect on secretion of lysozyme and vitamin $\mathbf{B}_{12}$ binding protein from permeabilized neutrophils (Panels $A$ and B). In fact, H-7 appeared to significantly enhance release of $\beta$-glucuronidase in the presence of both GTP- $\gamma-\mathrm{S}$ and $\mathrm{Ca}^{2+}$ (Panel C). Similarly, mezerein (a protein kinase $\mathrm{C}$ agonist 

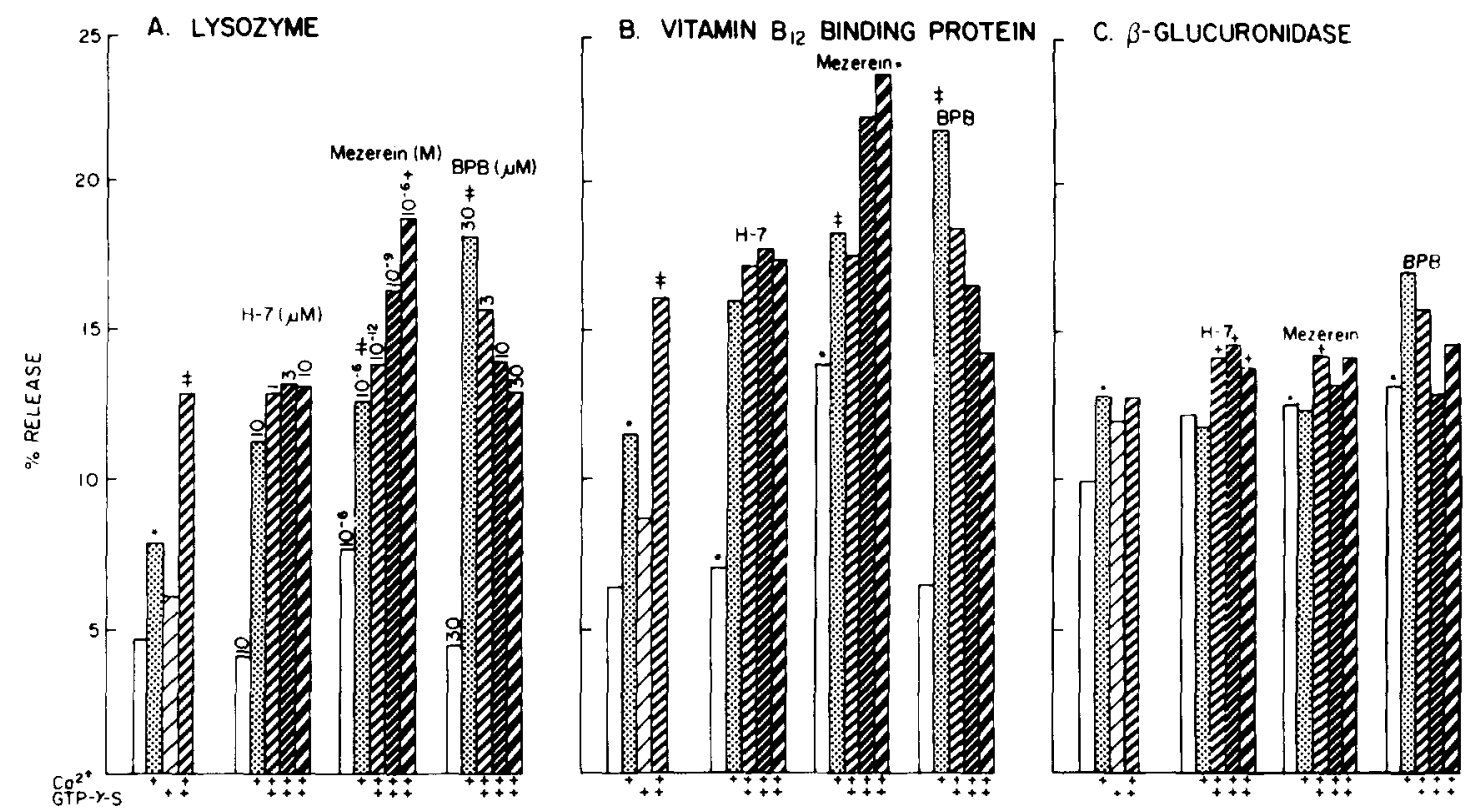

FIG. 5. Effects of inhibitors of protein kinase $\mathrm{C}$ and phospholipase $\mathrm{A}_{2}$ on synergy between $\mathrm{Ca}^{2+}$ and guanine nucleotides. Permeabilized neutrophils were incubated with $\mathrm{Ca}^{2+}(7 \mu \mathrm{M})$ and/or GTP- $\gamma-\mathrm{S}(5 \mu \mathrm{M})$ for $5 \mathrm{~min}$ at $37^{\circ} \mathrm{C}$. Where indicated, $\mathrm{H}-7\left(10^{-9}-10^{-6} \mathrm{M}\right)$, Mezerein $(1-10 \mu \mathrm{M})$, and $p$-bromophenacyl bromide (BPB; 3-30 $\mu \mathrm{M}$ ) were also present during 5 min preincubation. Release of lysozyme (Panel A), vitamin $\mathbf{B}_{12}$ binding protein (Panel B), and $\beta$-glucuronidase (Panel C) are shown. The results are a compilation of 3-5 experiments for each condition. Statistical significance $(P<0.05)$ was determined by a paired Student $t$-test and are denoted as follows: *indicates a significant difference when cells were incubated without additions; $\ddagger$ indicates a significant difference when cells were incubated with $\mathrm{Ca}^{2+}$ alone; +indicates a significant difference when cells were incubated with $\mathrm{Ca}^{2+}$ and GTP- $\gamma-\mathrm{S}$.

at high concentrations and antagonist at low concentrations) $[23,45]$ had little or no effect on secretion from permeabilized cells in the inhibitory range (Fig. 5). At higher concentrations, this compound enhanced both resting and $\mathrm{Ca}^{2+}$-induced secretion. Finally, we looked at p-bromophenacyl bromide (BPB), a phospholipase $A_{2}$ inhibitor [46]. Arachidonic acid, whose derivatives may play crucial roles in stimulusresponse coupling, can be derived from hydrolysis of diacylglycerols as well as from the action of phospholipase $\mathrm{A}_{2}$ on phospholipids. It was therefore desirable to see if inhibition of this enzyme (and, by implication, mobilization of arachidonic acid) affected secretion by permeabilized neutrophils. As can be seen in Fig. 5, concentrations of BPB which substantially inhibited intact cell function were without effect upon the synergy displayed by permeabilized cells. At low concentrations, synergy was actually enhanced by BPB. This compound very substantially enhanced $\mathrm{Ca}^{2+}$-induced secretion of lysozyme and vitamin $\mathbf{B}_{12}$ binding protein.

\section{DISCUSSION}

A simplistic interpretation of the 'standard model' of intracellular signal transduction, described in the Introduction, would predict that PKC plays an obligatory stimulatory role in secretion. Under this model, it was no surprise that the putative phospholipase $\mathrm{C}$ inhibitor, neomycin, could block secretion in permeabilized cells $[30,33]$. It was no surprise that $\mathrm{Ca}^{2+}$, either alone or synergistically with guanine nucleotides, could stimulate $\mathrm{IP}_{3}$ production [28, 42], a result which we confirmed in this 
work. With the role of phospholipase $\mathrm{C}$ apparently well established, we wished to see if the next link in the signal transduction chain, namely $\mathrm{PKC}$, was operative. Our results were not in accord with this hypothesis.

Instead, we found that Mg-ATP, an obligate substrate for PKC, was not required for secretion by permeabilized neutrophils. We found that the PKC agonists, PMA and OAG, did indeed produce some secretion on their own, but that this could be attributed to intact cell contamination. We also found that the PKC agonists did not overcome the block by neomycin and that the antagonists were not effective against degranulation. In fact, the inhibitors often enhanced secretion, virtually eliminating a role for $\mathrm{PKC}$ as a positive effector.

The source of this paradox lies in the assumption that phospholipase $\mathrm{C}$ activity is obligatory, as suggested by the neomycin data. Indeed, the specificity of neomycin is in some dispute. When employed in broken cell or permeabilized cell systems, submillimolar concentrations of this drug can be demonstrated to block phospholipase $C$ activity $[47,48]$. In contrast to our studies, concentrations of neomycin sufficient to block phospholipase $\mathrm{C}$ do not inhibit $\mathrm{Ca}^{2+}$ - and guanine nucleotide-supported secretion by permeabilized mast cells [48]; this has been used as evidence for the role of at least one other G-protein (not linked to phospholipase $\mathrm{C}$ ) in the degranulation process. However, millimolar concentrations of neomycin, often required when studying intact cells, and even submillimolar levels of the drug have been reported to have non-specific effects, including agonist actions [49-52].

Thus, on the basis of suspect neomycin data, we looked to see if the products of phospholipase $\mathrm{C}$, namely $\mathrm{IP}_{3}$ and diacylglycerol, were involved in $\mathrm{Ca}^{2+}$-induced lysosomal enzyme release or synergy with guanine nucleotides. $\mathrm{IP}_{3}$ proved to be without effect (unpublished results), but this would be expected since the buffer system we employed contained $1 \mathrm{mM}$ EGTA and would be able to absorb any $\mathrm{Ca}^{2+}$ liberated by $\mathrm{IP}_{3}$. A synthetic diacylglycerol, namely OAG, did additionally stimulate $\mathrm{Ca}^{2+}$. induced secretion; however, this synergy was weak and could be largely attributed to 'intact cell' contamination. Since diacylglycerols are known to be agonists of protein kinase $\mathrm{C}$, we examined another stimulant of this enzyme, namely PMA, and found enhancement of secretion without synergy. These data thus provide no support for the notion that inhibition by neomycin was due to failure to activate $\mathrm{PKC}$ 'downstream'.

The lack of a role for PKC in secretion in the permeabilized system is not unexpected since a vital substrate of this enzyme, ATP, would leak out of the cells; furthermore, our observations were not changed when Mg-ATP was added to these cells (Tables 1 and 2). Depending upon the cell type and permeabilization method employed, the role of ATP can range from none $[24,25,53-58]$ to enhancing [59-61] to required [29, 62-64]. The lack of an ATP requirement has led other investigators to conclude that PKC was not involved in platelet secretion [53]. ATP has been found to be inhibitory under some conditions [54], as shown in Table 2. That the effects of PMA and OAG are not necessarily identical, although they have the same putative target enzyme, has been well documented in a variety of systems $[65,66]$; thus, minor differences between the effects of these agonists do not shed any light upon the role, or lack thereof, of PKC in the permeabilized cell system. Furthermore, the generation of diacylglycerol per se would not necessarily lead to activation of PKC; some diacylglycerols are alkyl-linked [67] and these can lead to the inhibition, rather than activation, of PKC [68]. However, it should be noted that for bovine chromaffin cells, similar experiments provided evidence for involvement of PKC [69]; this is likely due to differences in the cell type employed.

Additional data suggest that the role, if any, of PKC in secretion by permeabilized neutrophils cannot be profound. OAG can stimulate only about $15 \%$ lysozyme or vitamin $B_{12}$ binding protein release while PMA evokes even less response. Furthermore, this stimulation takes place in the absence of exogenous ATP and in 
TABLE 2. EFFECT OF Mg-ATP ON $\mathrm{Ca}^{2+}$-INDUCED SECRETION FROM PERMEABILIZED hUMAN NEUTROPHILS

\begin{tabular}{|c|c|c|c|c|}
\hline \multicolumn{5}{|c|}{ Washed cells } \\
\hline & $\mathrm{Ca}^{2+}$ & GTP- $\gamma-\mathrm{S}$ & -Mg-ATP & $+\mathrm{Mg}-\mathrm{ATP}$ \\
\hline Vitamin $B_{12}$ & 0 & - & $1.5 \pm 0.4(n=13)$ & $3.0 \pm 1.8(n=6)$ \\
\hline Binding & 5 & - & $1.3 \pm 0.4(n=12)$ & $5.0 \pm 1.6^{*}(n=7)$ \\
\hline \multirow[t]{3}{*}{ Protein } & 30 & - & $18.4 \pm 2.7(n=6)$ & $14.4 \pm 3.6(n=6)$ \\
\hline & 0 & 5 & N.D. & N.D. \\
\hline & 5 & 5 & $4.4 \pm 1.1(n=8)$ & $4.5 \pm 1.0(n=8)$ \\
\hline \multirow[t]{5}{*}{ Lysozyme } & 0 & - & $1.7 \pm 0.4(n=13)$ & $1.9 \pm 0.2(n=6)$ \\
\hline & 5 & - & $1.1 \pm 0.3(n=12)$ & $2.7 \pm 0.4^{*}(n=7)$ \\
\hline & 30 & - & $18.7 \pm 3.2(n=6)$ & $12.4 \pm 2.9^{*}(n=6)$ \\
\hline & 0 & 5 & N.D. & N.D. \\
\hline & 5 & 5 & $4.5 \pm 1.1 \quad(n=8)$ & $6.1 \pm 1.2(n=8)$ \\
\hline \multirow[t]{5}{*}{$\beta$-Glucuronidase } & 0 & - & $3.8 \pm 0.3(n=13)$ & $6.2 \pm 0.9+(n=6)$ \\
\hline & 5 & 一 & $3.7 \pm 0.4(n=12)$ & $5.2 \pm 0.8 \dagger(n=7)$ \\
\hline & 30 & 一 & $13.7 \pm 2.3(n=7)$ & $8.8 \pm 1.4(n=6)$ \\
\hline & 0 & 5 & N.D. & N.D. \\
\hline & 5 & 5 & $4.4 \pm 0.6(n=8)$ & $7.0 \pm 0.7 \S(n=8)$ \\
\hline
\end{tabular}

Permeabilized neutrophils were washed twice in buffer before use. N.D. indicates conditions not done. See the legend to Table 1 for further details.

the presence of $1 \mathrm{mM}$ EGTA; since protein kinase $\mathrm{C}$ is activated by low concentrations of $\mathrm{Ca}^{2+}$, then only basal, non-calcium-dependent activity of this enzyme could be involved (if any). The protein kinase $\mathrm{C}$ antagonists $\mathrm{H}-7$ and mezerein also have no inhibitory effect on $\mathrm{Ca}^{2+}$ induced secretion, either in the presence or absence of guanine nucleotides. However, high concentrations of mezerein, which stimulate intact cells $[23,45]$, also stimulate permeabilized neutrophils; it is intriguing to speculate that this agent (as well as traditional protein kinase $\mathrm{C}$ agonists) might interact with some important transduction mechanisms in addition to the expected enzyme. Furthermore, if neomycin were serving merely to block production of diacylglycerols which were necessary for protein kinase $\mathrm{C}$ activation, then $\mathrm{OAG}$ should overcome the block. We did not observe this, although it is also possible that neomycin could diminish the availability of OAG in this system. Finally, since diacylglycerol is a source of arachidonic acid, which along with its oxygenated derivatives are potent agonists of neutrophils, we attempted to block another source of this fatty acid by inhibiting phospholipase $A_{2}$ with BPB. Concentrations of the inhibitor which blocked intact cell function [70] were without effect on permeabilized cells. In fact, this compound was often stimulatory. This suggests either that arachidonic acid release is not required for secretion from permeabilized neutrophils or that diacylglycerol provides a suffcient source. These results contrast with those reported for rat mast cells [71] wherein secretion was completely blocked by $10 \mu \mathrm{M} \mathrm{BPB}$; these differences may be due to species and or cell type.

In summary, we found no evidence to suggest that PKC activation plays an obligatory, stimulatory role in $\mathrm{Ca}^{2+}$-induced secretion from permeabilized neutrophils. These results also cast doubt upon the customary interpretation of experiments employing neomycin.

\section{REFERENCES}

1. Snyderman R., Pike M. C., Edge S. and Lane B. (1984) J. biol. Chem. 98, 444-448.

2. Sklar L. A., Bokoch G. M., Button D. and Smolen J. E. (1987) J. biol. Chem. 262, 135-139. 
3. Spiegel A. M., Gierschik P., Levine M. A. and Downs R. W., Jr. (1985) New Engl. J. Med. 312, 26-33.

4. Ng D. S. and Wong K. (1986) Biochem. biophys. Res. Commun. 141, 353-359.

5. Bokoch G. M. and Gilman A. G. (1984) Cell 39, 301-308.

6. Goldman D. W., Chang F. H., Gifford L. A., Goetzl E. J. and Bourne H. R. (1985) J. exp. Med. 162, 145-156.

7. Scott S. J., Olson C. V. and Lad P. M. (1988) Molec. Immun. 25, 305-311.

8. Gierschik P., Falloon J., Milligan G., Pines M., Gallin J. I. and Spiegel A. (1986) J. biol. Chem. 261, 8058-8062.

9. Gierschik P., Sidiropoulos D., Spiegel A. and Jakobs K. H. (1987) Eur. J. Biochem. 165, 185-194.

10. Bokoch G. M., Bickford K. and Bohl B. P. (1988) J. Cell Biol. 106, 1927-1936.

11. Murphy P. M., Eide B., Goldsmith P., Brann M., Gierschik P., Spiegel A. and Malech H. L. (1987) FEBS Lett. 221, 81-86.

12. Bokoch G. M. and Parkos C. A. (1988) FEBS Lett. 227, 66-70.

13. Northrup J. K. (1985) Molecular Mechanisms of Transmembrane Signalling (Cohen P. and Houslay M., Eds), Elsevier Science Publishers B.V., 91-116.

14. Becker E. L., Kermode J. C., Naccache P. H., Yassin R., Munoz J. J., Marsh M. L., Huang C. K. and Sha'afi R. I. (1986) Fed. Proc. 45, 21512155 .

15. Cockcroft S., Baldwin J. M. and Allan D. (1984) Biochem. J. 221, 477-482.

16. Shak S. and Goldstein I. M. (1984) J. biol. Chem. 259, 10181-10187.

17. Bradford P. G. and Rubin R. P. (1985) Molec. Pharmac. 27, 74-78.

18. Dougherty R. W., Godfrey P. P., Hoyle P. C., Putney J. W., Jr. and Freer R. J. (1984) Biochem. J. 222, 307-314.

19. Ohta H., Okajima F. and Ui M. (1985) J. biol. Chem. 260, 15771-15780.

20. Prentki M., Wollheim C. B. and Lew P. D. (1984) J. biol. Chem. 259, 13777-13782.

21. Bradford P. G. and Rubin R. P. (1986) J. biol. Chem. 261, 15644-15647.

22. Krause K. H. and Lew P. D. (1987) J. clin. Invest. 80, 107-116.

23. O'Flaherty J. T., Schmitt J. D., Wykle R. L., Redman J. F., Jr. and McCall C. E. (1985) $J$. cell. Physiol. 125, 192-199.

24. Smolen J. E. and Stoehr S. J. (1985) J. Immun. 134, 1859-1865.

25. Smolen J. E., Stoehr S. J. and Boxer L. A. (1986) Biochim. biophys. Acta 886, 1-17.
26. Smolen J. E., Todd R. F., III and Boxer L. A. (1986) Am J. Pathol. 124, 281-285.

27. Barrowman M. M., Cockcroft S. and Gomperts B. D. (1986) Nature 319, 504-507.

28. Gomperts B. D., Barrowman M. M. and Cockcroft S. (1986) Fed. Proc. 45, 2156-2161.

29. Barrowman M. M., Cockcroft S. and Gomperts B. D. (1987) J. Physiol. 383, 115-124.

30. Smolen J. E., Stoehr S. J., Traynor A. E. and Sklar L. A. (1987) J. Leuk. Biol. 41, 8-13.

31. Smolen J. E. and Stoehr S. J. (1986) Biochim. biophys. Acta 889, 171-178.

32. Cockcroft S. and Gomperts B. D. (1985) Nature 314, 534-536.

33. Streb H., Heslop J. P., Irvine R. F., Schulz I. and Berridge M. J. (1985) J. biol. Chem. 260, 73097315.

34. Boyum A. (1968) Scand. J. clin. Lab. Invest. 21, 77-89.

35. Zurier R. B., Hoffstein S. and Weissmann G. (1973) Proc. natn. Acad. Sci., U.S.A. 70, 844-848.

36. Bers D. M. (1982) Am J. Physiol. 242, C404 C408.

37. Brittinger G. R., Hirschhorn R., Douglas S. D. and Weissmann G. (1968) J. Cell Biol. 37, 394 411 .

38. (1972) Worthington Enzyme Manual, 100-101.

39. Smith G. P. and Peters T. J. (1982) Biochim. biophys. Acta 719, 304-308.

40. Wacker W. E. C., Ulmer D. D. and Vallee B. L. (1956) New Eng. J. Med. 255, 449-456.

41. Palmer S., Hughes K. T., Lee D. Y. and Wakelam M. J. O. (1989) Cell. Signal. 1, 147 156.

42. Bradford P. G. and Rubin R. P. (1986) Biochem. J. 239, 97-102.

43. McPhail L. C., Clayton C. C. and Snyderman R. (1984) Science 224, 622-625.

44. O'Flaherty J. T., Schmitt J. D. and Wykle R. L. (1985) Biochem. biophys. Res. Commun. 127, 916-923.

45. Naccache P. H., Molski M. M., Volpi M., Shefcyk J., Molski T. F., Loew L., Becker E. L. and Sha'afi R. I. (1986) J. Leuk. Biol. 40, 533548.

46. Roberts M. F., Deemer R. A., Mincey T. C. and Dennis E. A. (1977) J. biol. Chem. 252, 2405 2410 .

47. Rock C. O. and Jackowski S. (1987) J. biol. Chem. 262, 5491-5498.

48. Cockcroft S., Howell T. W. and Gomperts B. D. (1987) J. Cell Biol. 105, 2745-2750.

49. Siess W. and Lapetina E. G. (1986) FEBS Lett. 207, 53-57.

50. Polascik T., Godfrey P. P. and Watson S. P. (1987) Biochem. J. $243815-819$. 
51. Nakashima S., Tohmatsu T., Shirato L., Takenaka A. and Nozawa Y. (1987) Biochem. biophys. Res. Commun. 146, 820-826.

52. Tysnes 0.-B., Steen V. M. and Holmsen H. (1988) Eur. J. Biochem. 177, 219-223.

53. Ruggiero M., Zimmerman T. P. and Lapetina E. G. (1985) Biochem. biophys. Res. Commun. 131, 620-627.

54. Howell T. W. and Gomperts B. D. (1987) Biochim. biophys. Acta 927, 177-183.

55. Howell T. W., Cockcroft S. and Gomperts B. D. (1987) J. Cell Biol. 105, 191-197.

56. Takuma T. and Ichida T. (1988) J. Biochem. 103, 95-98.

57. Nakanishi A., Morita K. and Oka M. (1988) Jap. J. Pharmac. 46, 109-115.

58. Stutchfield J. and Cockeroft S. (1988) Biochem J. 250, 375-382.

59. Dunn L. A. and Holz R. W. (1983) J. biol. Chem. 258, 4989-4993.

60. Lee S. A. and Holz R. W. (1986) J. biol. Chem. 261, 17089-17098.

61. Schafer T., Karli U. O., Gratwohl E. K., Schweizer F. E. and Burger M. M. (1987) $J$. Neurochem. 49, 1697-1707.
62. Knight D. E. and Baker P. F. (1982) J. Mem. Biol. 68, 107-140.

63. Morita K., Ishii S., Uda H. and Oka M. (1988) J. Neurochem. 50, 644-648.

64. Ahnert Hilger G., Brautigam M. and Gratzl M. (1987) Biochemistry 26, 7842-7848.

65. Brooks R. C., Morell P., DeGeorge J. J., McCarthy K. D. and Lapetina E. G. (1987) Biochem. biophys. Res. Commun. 148, 701-708.

66. Nourshargh S. and Hoult J. R. (1987) Br. J. Pharmac. 91, 557-568.

67. Rider L. G., Dougherty R. W. and Niedel J. E. (1988) J. Immun. 140, 200-207.

68. Daniel L. W., Small G. W. and Schmitt J. D. (1988) Biochem. biophys. Res. Commun. 151, 291-297.

69. Knight D. E., Sugden D. and Baker P. F. (1988) J. Mem. Biol. 104, 21-34.

70. Smolen J. E. and Weissmann G. (1979) Biochem. Pharmac. 29, 533-538.

71. Sorimachi M., Nishimura S. and Sadano H. (1987) Biomed. Res. 8, 205-209. 